\title{
EFFICACY OF NITROGLYCERINE INFUSION VERSUS SUBLINGUAL NIFEDIPINE IN SEVERE PRE-ECLAMPSIA
}

\author{
By
Emad Lamloum Abd El-Hamid, Ismail Abd El-Azim Mira, Hani Maged Abd El-Aal and Farid Ahmed Kassab \\ Department of Obstetrics \& Gynecology, Faculty of Medicine, Al-Azhar University, Cairo \\ Corresponding author: Emad Lamloum Abd El-Hamid, \\ E-mail: emad_lamloum@gmail.com
}

\begin{abstract}
Background: Pre-eclampsia is a pregnancy-specific syndrome of reduced organ perfusion secondary to vasospasm and endothelial activation. The incidence of preeclampsia is estimated to range between 2.5 and $5 \%$. An accurate estimate, as well as its global burden, is difficult to obtain, due to lack of data from several countries and standardization of diagnostic criteria.
\end{abstract}

Objective: To compare between the uses of continuous i.v. administration of nitroglycerine versus sublingual nifedipine in the management of women with severe pre-eclampsia who were being managed with controlled plasma volume expansion and $\mathrm{MgSO} 4$ loading and maintenance doses.

Patients and Methods: Patients were taken from Sayed Galal Hospital. This study was carried out on 100 women with severe pre-eclampsia who were being managed with controlled plasma volume expansion and $\mathrm{MgSO} 4$ loading and maintenance doses. Those women were randomly assigned into two equal groups: Nitroglycerine or nifedipine. Both groups were compared as regard maternal adverse effects of vasodilator therapy, mean arterial pressure changes within one hour after vasodilator therapy, post therapy changes in fetal cardiotocography (CTG) and for feto-maternal complications including gestational age of termination of pregnancy, time of maternal intensive care unit (ICU) stay and the need of neonatal ICU.

Results: Statistical analysis of the magnitude and time course of maternal hypotensive responses after initiation of the vasodilator therapy showed that, in nitroglycerine group, a statistically significant decrease in both systolic blood pressure (SBP) and diastolic blood pressure (DBP) started just $5 \mathrm{~min}$. after the initiation of nitroglycerine infusion, while in nifedipine group, the significant decrease in SBP and DBP started 15 min. after oral nifedipine. The SBP and DBP measurements in nitroglycerine group were significantly lower than those in nifedipine group. The feto-maternal safety margin observed was similar in the two study groups.

Conclusion: IV infusion of nitroglycerine was effective, safe and alternative therapy for severe preeclampsia.

Keywords: Pre-eclampsia, Nitroglycerine, Nifedipine, ICU.

\section{INTRODUCTION}

Pre-eclampsia is a pregnancy-specific syndrome of reduced organ perfusion secondary to vasospasm and endothelial activation. Proteinuria is an important sign of pre-eclampsia (Mol et al., 2016).
The most accredited pathogenetic theory of preeclampsia is based on unbalanced angiogenic and antiangiogenic factors (Goulopoulou and Davidge, 2015). In preeclampsia, there is increased expression of soluble fms-like 
tyrosine kinase-1 (sFlt1), also called VEGFR1, the soluble form of the receptor for vascular endothelial growth factor (VEGF), which is a pro-angiogenic cytokine produced by macrophages, $\mathrm{T}$ cells, tumor cells, and cytotrophoblast, and it is involved in angiogenesis and vasculogenesis. Concurrently, a decreased production of placental growth factor (PIGF) occurs. PlGF is also an angiogenic factor belonging to the VEGF family which exists in four isoforms PlGF-1, PlGF-2, PlGF-3, and PlGF-4 (Goulopoulou and Davidge, 2015).

Lower maternal levels of PIGF have greater accuracy (area under ROC curve 0.85 ) in the prediction of superimposed preeclampsia, compared to other biomarkers such as B-type natriuretic peptide (BNP), neutrophil gelatinaseassociated lipocalin (NGAL), and serum relax in concentrations (Bramham et al., 2016).

Preeclampsia is a heterogeneous disease, at times difficult to diagnose, due to the wide range of clinical presentation and the lack of diagnostic tests with adequate sensitivity and specificity. Classification considered a diagnosis of preeclampsia in the absence of proteinuria, when signs of maternal organ or fetoplacental dysfunction are present (Magee et al., 2015).

Nifedipine is a dihydropyridine calcium channel blocker. Its main uses are as an antianginal and antihypertensive, although a large number of other uses have been found for this agent such as Raynaud's phenomenon, premature labor, and painful spasms of the esophagus in cancer and tetanus patients. It is also commonly used for the small subset of pulmonary hypertension patients whose symptoms respond to calcium channel blockers (Poole-Wilson et al., 2011).

Nitroglycerine, a nitric oxide donor with low oral bioavailability and a very short half-life, has a potent venodilator effect in low doses and affects arterial tone at high doses. Owing to its effective tocolytic action, nitroglycerine has been used in different obstetric emergencies and as a uterine relaxant during fetal surgery. Nitroglycerine also has a low level of toxicity and its most commonly reported adverse effect is headache. Even so, information regarding the use of continuous intravenous administration of nitroglycerine as an antihypertensive agent in the management of pre-eclampsia is scarce (Cetin et al., 2014). S-nitro glutathione is a nitric oxide donor and a potent inhibitor of platelet activation at doses that do not lower blood pressure. It is also used in the prevention and treatment of HELLP syndrome. Its infusion for 90 minutes results in a rapid improvement of patient hematology, liver biochemistry and renal functions (Valensise et al., 2010).

The aim of the present study was to compare between the use of continuous i.v. administration of nitroglycerine versus sublingual nifedipine in the management of women with severe pre-eclampsia who are being managed with controlled plasma volume expansion and $\mathrm{MgSO} 4$ loading and maintenance doses.

\section{PATIENTS AND METHODS}

This study was held at the Gynecology and Obstetrics Department of Sayed Galal Hospital, during the period from March, 2017 to December, 2018. 
After ethical committee and consent from the patients, this study was carried out on 100 women with severe preeclampsia who were being managed with controlled plasma volume expansion and MgSO4 loading and maintenance doses. Those women were randomly assigned to equal groups: nitroglycerine or nifedipine treatment.

Study Design: A Randomized Controlled Clinical Trail.

\section{Inclusion criteria:}

- Age group between 25-35 years.

- A pregnancy between 20-32 weeks.

- Not in labor.

- Singleton or multiple fetuses.

- With uncomplicated severe preeclampsia.

\section{Exclusion criteria:}

- Imminence of eclampsia.

- Clinical manifestations of target organ damage.

- History of chronic hypertension, antihypertensive therapy.

- Life-threatening fetal heart beat changes.

- Heart and Renal Diseases.

- Diabetes Mellitus.

Blood pressure, abdominal ultrasound, routine blood and urine chemistry tests were performed. These parameters, along with fetal heart rate, were recorded. An i.v. infusion of Ringer's lactate solution was initiated $(8 \mathrm{~mL} / \mathrm{kg}$ per $\mathrm{h})$ in order to induce a small ( $<1 \%$ of bodyweight) but controlled extracellular volume expansion. One hour later, the infusion rate was reduced to $1 \mathrm{~mL} / \mathrm{kg}$ per $\mathrm{h}$ and a loading dose $(4 \mathrm{~g} / 250 \mathrm{~mL})$ of $\mathrm{MgSO} 4$ was i.v. administered over $30 \mathrm{~min}$. This loading dose was followed by an i.v. infusion of $1 \mathrm{~g} / \mathrm{h} \mathrm{MgSO} 4$ for up to $8 \mathrm{~h}$ post-partum.

In the nitroglycerine group, $5 \mu \mathrm{g} / \mathrm{min}$ nitroglycerine $(25 \mu \mathrm{L} / \mathrm{min}) \quad$ was administered by continuous i.v. infusion with increases in dose of $5 \mu \mathrm{g} / \mathrm{min}$ (25 $\mu \mathrm{L} / \mathrm{min}$ ) every 5 min until the therapeutic goal was reached, which was a decrease in systolic blood pressure (SBP) to 120 - 140 $\mathrm{mmHg}$ and a decrease in diastolic blood pressure (DBP) to $80-90 \mathrm{mmHg}$ within the first hour of treatment. In almost all intensive care units in our hospitals, physicians use intravenous nitroglycerine infusion (Nitronal, POHL BOSKAMP, Germany - Tridil, Galaxo, UK) for management of severe hypertension.

In the nifedipine group, the content $(100 \mu \mathrm{L})$ of a $10 \mathrm{mg}$ capsule of nifedipine was drawn up into an insulin syringe and deposited sublingually, every $30 \mathrm{~min}$ as required. In Egypt, nifedipine (sold under the brand name, adalat, procardia, others) was available and inexpensive for our resources.

Statistical in nitroglycerine group, a statistically significant decrease in both SBP and DBP started just $5 \mathrm{~min}$. after the initiation of nitroglycerine infusion while in nifedipine group, the significant decrease in SBP and DBP started 15 min. after oral nifedipine. In addition, there were statistically significant differences in SBP and DBP between the two groups which appeared 5 min after administration of the vasodilator therapy and continued throughout all the 5 min-intervals after therapy. The SBP and DBP measurements 
in nitroglycerine group were significantly lower than these in nifedipine group.

\section{Statistical analysis:}

Recorded data were analyzed using the statistical package for social sciences, version 20.0 (SPSS Inc., Chicago, Illinois, USA). Quantitative data were expressed as mean \pm standard deviation (SD). Qualitative data were expressed as frequency and percentage. Independent- samples t-test of significance was used when comparing between two means. Chisquare (x2) test of significance was used in order to compare proportions between two qualitative parameters. The confidence interval was set to $95 \%$ and the margin of error accepted was set to $5 \%$. The p-value was considered significant when $\mathrm{P}$-value $<0.05$.

\section{RESULTS}

Majority of neonates in both groups $(80 \%)$ hadn't any of the Neonatal Complications without statistically significant differences between both groups.

There were no statistically significant differences between both groups regarding Time of conservation until termination of pregnancy. There was a statistically significant increase in gestational age until onset of termination in Nitroglycerine group. There were no cases who continue pregnancy after 32 weeks in the Nifedipine Group. There were significant differences in the time of conservation at gestational age 30-32 weeks.

Maternal Tachycardia that occurred during vasodilator therapy was significantly Higher among Nifedipine Group where $(40 \%)$ of cases had Tachycardia vs. $(20 \%)$ of cases in Nitroglycerine Group with a significant pvalue $=0.024$ (Table 1$)$.

Table (1): Neonatal Complications (24h after delivery) that occurred after vasodilator, Maternal Tachycardia that occurred during vasodilator therapy and Maternal Tachycardia that occurred during vasodilator among patients according to treatment allocation (No \& \%)

\begin{tabular}{|c|c|c|c|}
\hline $\begin{array}{ll}\text { Parameters } & \text { Groups } \\
\end{array}$ & $\begin{array}{c}\begin{array}{c}\text { Nitroglycerine Group } \\
\mathbf{N}=\mathbf{5 0}\end{array} \\
\end{array}$ & $\begin{array}{c}\text { Nifedipine Group } \\
\mathbf{N}=\mathbf{5 0}\end{array}$ & P-value \\
\hline \multicolumn{4}{|l|}{ Neonatal Complications: } \\
\hline \begin{tabular}{l|l} 
Nothing \\
\end{tabular} & $40(80.0)$ & $40(80.0)$ & \multirow{5}{*}{0.976} \\
\hline Fetal Stillbirth & $2(4.0)$ & $2(4.0)$ & \\
\hline Fetal Distress & $4(8.0)$ & $3(6.0)$ & \\
\hline Apgar 1 min $<7$ & $3(6.0)$ & $3(6.0)$ & \\
\hline Apgar 5 min $<7$ & $1(2.0)$ & $2(4.0)$ & \\
\hline \multicolumn{4}{|l|}{ Tachycardia: } \\
\hline \begin{tabular}{l|l} 
No \\
\end{tabular} & $40(80.0)$ & $30(60.0)$ & \multirow[t]{2}{*}{0.024} \\
\hline \begin{tabular}{l|l} 
Yes \\
\end{tabular} & $10(20.0)$ & $20(40.0)$ & \\
\hline \multicolumn{4}{|c|}{ Gestational age at onset of termination (weeks): } \\
\hline \begin{tabular}{|l|l}
24 & up to 26 \\
\end{tabular} & $11(22.0)$ & $12(24.0)$ & \multirow[t]{5}{*}{0.078} \\
\hline 26 up to 28 weeks & $5(10.0)$ & $18(36.0)$ & \\
\hline 28 up to 30 weeks & $13(26.0)$ & $12(24.0)$ & \\
\hline 30 up to 32 weeks & $17(34.0)$ & $8(16.0)$ & \\
\hline$>32$ weeks & $4(8.0)$ & $0(0.00)$ & \\
\hline
\end{tabular}


Table (2): shows that there were statistically significant differences in MAP between the two groups which started 5 min. after administration of the vasodilator therapy and continued throughout all the 5 min-intervals after therapy. The MAP measurements in nitroglycerine group were significantly lower than these in nifedipine group after 20 min of administration $(\mathrm{P}<0.001)$.

Table (2): MAP changes within one hour after vasodilator therapy according to treatment allocation (Mean \pm SD)

\begin{tabular}{|l|c|c|c|}
\hline GAP & $\begin{array}{c}\text { Nitroglycerine Group } \\
\mathbf{N = \mathbf { 5 0 }}\end{array}$ & $\begin{array}{c}\text { Nifedipine Group } \\
\mathbf{N}=\mathbf{5 0}\end{array}$ & P-value \\
\hline Basal & $122.72 \pm 2.9$ & $125.04 \pm 2.9$ & $\mathbf{0 . 0 0 1}$ \\
\hline $\mathbf{1 0}$ min & $117.32 \pm 4.1$ & $115.82 \pm 3.1$ & $\mathbf{0 . 0 4 2}$ \\
\hline $\mathbf{2 0}$ min & $109.98 \pm 3.7$ & $110.08 \pm 4.0$ & 0.897 \\
\hline $\mathbf{3 0}$ min & $102.50 \pm 11.2$ & $109.16 \pm 3.7$ & $\mathbf{0 . 0 0 1}$ \\
\hline $\mathbf{4 0}$ min & $93.48 \pm 4.9$ & $106.80 \pm 4.9$ & $\mathbf{0 . 0 0 1}$ \\
\hline $\mathbf{5 0}$ min & $96.28 \pm 3.2$ & $105.20 \pm 4.7$ & $\mathbf{0 . 0 0 1}$ \\
\hline $\mathbf{6 0}$ min & $94.78 \pm 3.9$ & $100.20 \pm 3.8$ & $\mathbf{0 . 0 0 1}$ \\
\hline
\end{tabular}

There was no significant difference between baseline and post-therapy cardiotocography (CTG) changes in nifedipine group $(\mathrm{P}>0.05)$ as regard FHR, baseline variability, accelerations, and fetal movements. Only one case showed a non-reactive CTG after therapy.

There was no significant difference between baseline and post-therapy FHR and fetal heart accelerations $(\mathrm{P}>0.05)$. There was a statistically significant increase in post-therapy baseline variability $(P=0.012)$. There was a statistically significant increase in posttherapy fetal movements ( $\mathrm{P}<0.001)$. There was no change in number of patients who showed a reactive CTG (Table 3).

Table (3): Baseline versus post-therapy Cardio-Toco-Graphy (CTG) changes in Nifedipine group and nitroglycerine group (gestational age: $20-32$ weeks) $($ Mean \pm SD)

\begin{tabular}{|c|c|c|c|}
\hline Parameters $\quad$ Duration & Baseline & Post-Therapy & P-value \\
\hline \multicolumn{4}{|l|}{ Nifedipine group: } \\
\hline FHR (Beat/min) & $148 \pm 9.1$ & $146.10 \pm 7.1$ & 0.339 \\
\hline Baseline variability (beats) & $12.5 \pm 5.2$ & $10.75 \pm 3.7$ & 0.078 \\
\hline Acceleration & $4.90 \pm 3.5$ & $4.30 \pm 3.2$ & 0.181 \\
\hline Fetal movement & $6.15 \pm 3.6$ & $5.85 \pm 2.6$ & 0.450 \\
\hline \multicolumn{4}{|l|}{ Nitroglycerine group: } \\
\hline FHR (Beat/min) & $150 \pm 8.7$ & $144.10 \pm 7.8$ & 0.331 \\
\hline Baseline variability (beats) & $9.90 \pm 5.2$ & $12.50 \pm 4.7$ & 0.021 \\
\hline Acceleration & $4.80 \pm 3.5$ & $5.50 \pm 2.9$ & 0.309 \\
\hline Fetal movement & $5.85 \pm 3.6$ & $9.35 \pm 4.1$ & 0.001 \\
\hline
\end{tabular}




\section{DISCUSSION}

Pre-eclampsia is a medical condition where hypertension arises in pregnancy in association with significant amounts of protein in urine. It is the most common of the dangerous pregnancy complications and it may affect both the mother and the fetus (Say et al., 2014).

In nitroglycerine group, a statistically significant decrease in both SBP and DBP started just 5 min. after the initiation of nitroglycerine infusion, while in nifedipine group the significant decrease in SBP and DBP started 15 min. after oral nifedipine. In addition, there were statistically significant differences in SBP and DBP between the two groups which appeared $5 \mathrm{~min}$ after administration of the vasodilator therapy and continued throughout all the 5 min-intervals after therapy. The SBP and DBP measurements in nitroglycerine group were significantly lower than these in nifedipine group. Maternal heart rate was similar in both groups before therapy, but after therapy heart rate increased significantly in both groups and this increase was significantly larger in nifedipine treated group than in nitroglycerine-treated group

Alexander et al. (2014) and Foster et al. (2015) concluded that supplementation of nitric oxide donors significantly reduces the elevated blood pressure in preeclampsia.

Nevo et al. (2013) found significant reduction in maternal blood pressure and significant increase in maternal heart rate after nitroglycerine infusion. Cetin et al. (2014) found significant reduction in SBP and DBP after nitroglycerine infusion in women with severe preeclampsia, eclampsia and HELLP syndrome.
In this study, the therapeutic goal in nitroglycerine group was achieved after $17.50 \pm 3.441 \mathrm{~min}$. and required 10 to $25 \mu \mathrm{g} / \mathrm{min}$. The needed time was significantly shorter than that in nifedipine group and the required dose was 10 to 20 mg (one or two capsules). Thus, not only the hypotensive response of nitroglycerine started sooner, but also the therapeutic goal was achieved faster and with greater precision than with oral nifedipine. The same was reported by Manzur et al. (2010), who compared the therapeutic responses of the two drugs in 32 patients suffering from severe pre-eclampsia. They did not find any significant correlation between the patient's characteristics and the needed dose and time to achieve the therapeutic goal in both groups. Contrary to this, we found a significant positive correlation between patient weight and the dose and time needed to achieve the therapeutic goal within nitroglycerine group only. This could be attributed to the larger patient's number in our study compared to this in the above mentioned study. In the current study, no maternal complications occurred in both groups after therapy as showed by the clinical evaluation and the post-therapy laboratory investigations. There were no differences in maternal adverse effects between the two groups during administration of the vasodilator therapy and the most frequent adverse effect was headache.

In this study, electronic fetal monitoring showed that, within the nifedipine-treated group, there was no significant difference in all variables after therapy and only one patient showed a non-reactive CTG which cannot be attributed to nifedipine administration. With nitroglycerine-treated group, there 
was a statistically significant increase in fetal movements after therapy and all patients showed a reactive CTG. This was in agreement with Nevo et al. (2013), who found that administration of a nitric oxide donor does not exert adverse effect on the fetus, as reflected by FHR patterns and the decrease in number and size of FHR decelerations and the increase in the number of fetal movements suggest that donors of nitric oxide may improve the fetal condition.

In this study, the feto-maternal safety margin of nitroglycerine infusion was similar to that observed in the nifedipinetreated group. Thus, a continuous nitroglycerine infusion could be an alternative option for the management of patients with severe pre-eclampsia who are intolerant to oral drug administration or who require endotracheal intubation to induce general anaesthesia. This was in agreement with Longmire et al. (2010), who studied the hemodynamic effects of nitroglycerine infusion during endotracheal intubation in patients with severe pre-eclampsia. In addition, it has been reported that low concentrations of nitroglycerine inhibit the hypoxia / reoxygenation induced apoptosis observed in human chorionic villi in preeclamptic pregnancies (Belkacemi et al., 2010).

Contrary to these advantages, it has been documented that high dose (100$300 \mu \mathrm{g} / \mathrm{min}$ ) of nitroglycerine induces intracranial hypertension and decreases cerebral perfusion pressure (RangelCastillo et al., 2010).

\section{CONCLUSION}

Women with severe pre-eclampsia who suffered from severe hypertension after they were managed with $\mathrm{MgSO} 4$ loading and maintenance doses, a continuous infusion of intravenous nitroglycerine reduced blood pressure sooner, to a greater extent, faster and more precisely than the use of oral nifedipine. The fetomaternal safety margin observed was similar in the two study groups.

\section{REFERENCES}

1. Alexander BT, Cockrell KL, Massey MB, Bennett WA and Granger JP (2014): Tumor necrosis factor-alpha-induced hypertension in pregnant rats results in decreased renal neuronal nitric oxide synthatase expression. Am J Hypertens, 15(2 Pt 1): 170-5.

2. Belkacemi L, Bainbridge SA, Dickinison MA, Smith GN and Graham CH. (2010): Glyceryl trinitrate inhibits the hypoxia/reoxygenation-induced apoptosis in the syncytiotrophoblast of the human placenta. Am J Pathol., 170: 909-20.

3. Bramham K, Parnell B, Nelson-Piercy C, Seed PT, Poston L and Chappell LC (2014): Chronic hypertension and pregnancyoutcomes: systematic review and meta-analysis. BMJ, 348:2301-6.

4. Cetin A, Yurtcu N, Juvenal T, Imir AG, Duran B and Cetil M (2014): The effect of glyceryltrinitrate on hypertension in women with severe preeclampsia, HELLP syndrome and eclampsia. Hypertens. Pregnancy, 23: 3746.

5. Fong A, Chau CT, Pan D and Ogunyemi DA (2013): Clinical morbidities trends and demographics of eclampsia: a population based study. Am J Obstet Gynecol., 209:1-7.

6. Foster MW, Pawloski JR, Singel DJ and Stamler JS (2015): Role of circulating Snitrosothiols in control of blood pressure. Hypertension, 45 (1): 15-7.

7. Goulopoulou S and Davidge ST (2015): Molecular mechanisms of maternal vascular dysfunction in preeclampsia. Trends Mol Med., 21:88-97.

8. Longmire S, Leduc L, Jones MM, Hawkins JL, Joyce TH and Cotton DB (2010): The hemodynamic effects of intubation during 
EMAD LAMLOUM ABD EL-HAMID et al.,

nitroglycerine infusion in severe pre-eclampsia. Am J Obstet Gynecol., 154: 551-6.

9. Magee LE, Pels A and Helewa MD (2015): The hypertensive disorders of pregnancy (29.3). Best Pract Research Clin Oobstet Gynecol., 29:643-657.

10. Manzur S, Mandeville PB, Gordillo A Moscoso, Hernandez JF Sierra and Rodrigues-Martinez M. (2010): Efficacy of nitroglycerine infusion versus sublingual nifedipine in of severe pre-eclampsia. Clinical and Experimental Pharmacology and Physiology, 35: 580-85.

11. Mol BWJ, Roberts CT and Thangaratinam S (2016): Preeclampsia. Lancet, 387 (10022): 999-1011.

12. Nevo O, Thaler I, Shick V, Vortman T and Soustied JF (2013): The effect of isosorbide trinitrate, a donor of nitric oxide, on maternal cerebral blood flow in gestational hypertension and pre-eclampsia. Am. J. Obstet. Gynecol., 188 (5): 1360-5.
13. Poole-Wilson PA, Kirwan BA, Vokó Z, de Brouwer S, van Dalen FJ and Lubsen J (2011): Safety of nifedipine GITS in stable angina: the ACTION trial. Cardiovas Drugs Ther., 20(1): 45-54.

14. Rangel-Castillo L, Gopinath S, and Robertson S (2010): Management of Intracranial Hypertension. Neurol Clin., 26(2): $521-541$

15.Say L, Chou D, Gemmill A, Tunçalp O, MollerA and Alkema L (2014): Global causes of maternal death: a WHO systematic analysis. Lancet Glob Health, 2(6):323-33.

16. Valensise H, Vasapollo B, Novelli GP, Giorgi G, Verallo P, Galante A and Arduini D (2010): Maternal and fetal hemodynamic effects induced by nitric oxide donors and plasma volume expansion in pregnancies with gestational hypertension with absent enddiastolic flow in the umbilical artery. Ultrasound Obstet. Gynaecol., 31(1): 55-64. 


\section{فاعلية العلاج بالنيتروجليسرين عن طريق الوريد مقارنة

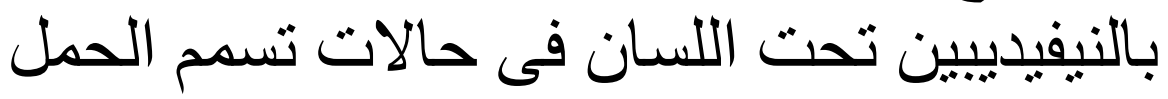

عماد لملوم عبدالحميد عبدالعزيز، إسماعيل عبد العظيم ميرة، هاني ماجد عبد العال،

$$
\text { فريد أحمد كساب }
$$

قسم أمراض النساء والتوليد، كلية الطب، جامعة الأزهر، القاهرة

خلفيـة البحـث: تسمم الحمل هـو مرض يحدث فيه ارتفاع لضغط الدم أثناء الحمل ويكون

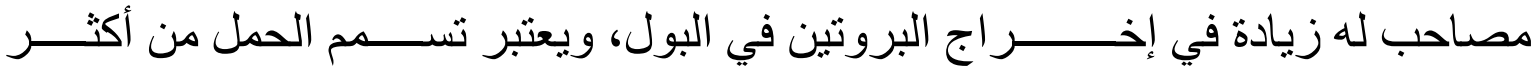

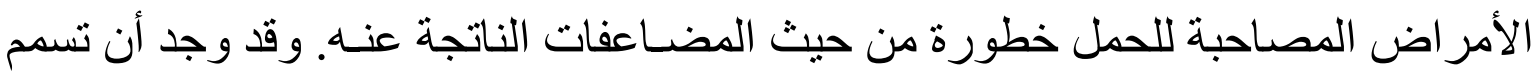

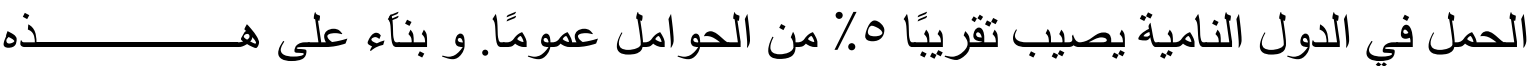
الإحصائيات، فان هذا المرض قد يودى بحياة • ـ ألف سيدة سنويًا في الدول النامية.

الهدف من البحث: در اسة كفاءة النيتروجلسرين عن طريق الوريد في علاج الارتفاع في

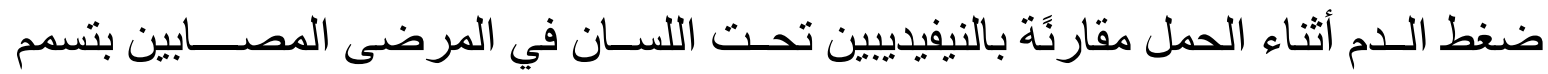

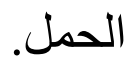

المريضـات وطرق البحث: تم إجر اء هذه الدر اسة على الحوامل المترددات على مستشفى

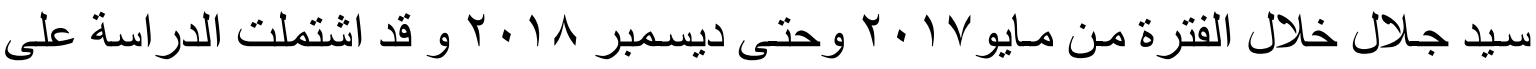

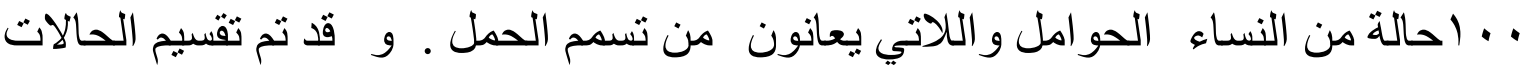

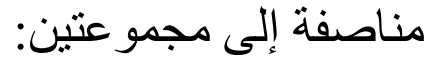

ا .مجموعة النيفيليبين تم إعطائها مادة النيفيديبين. Y.مجموعة النيتروجلسرين تم إعطائها مادة النيتروجليسرين. نتائج البحث: مجموعة النيفيديبين: إنخفاض ملحوظ لضغط الدم بعد مرور 10 دقيقة من بدء إعطاء العلاج .و قد كـــــــان منوسط الوقت اللازم لانخفاض ضغط الدم إلى الدرجة

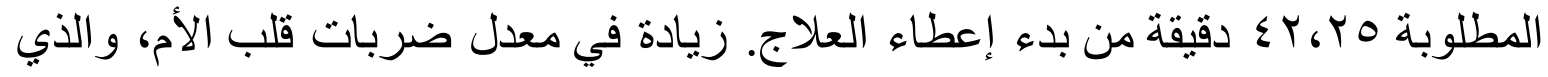


ارتفع إلى هو ضربة/ دقيقة بعد مرور ساعة من بدء إعطاءالعلاج. عدم حدوث تغير

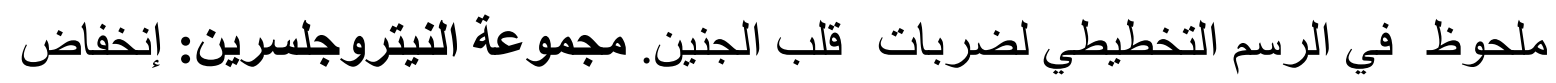

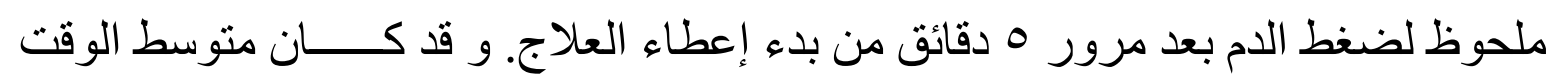

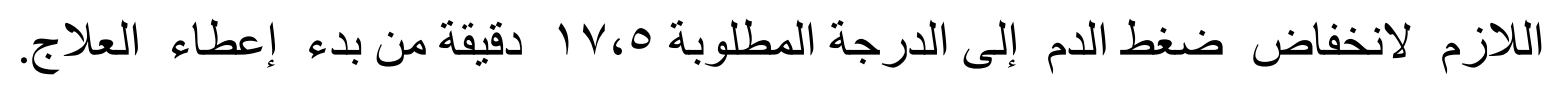

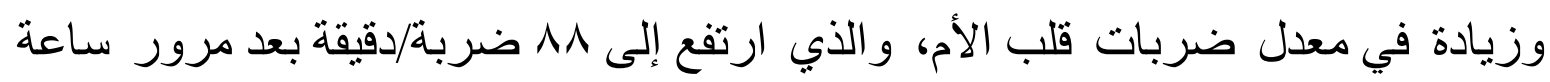

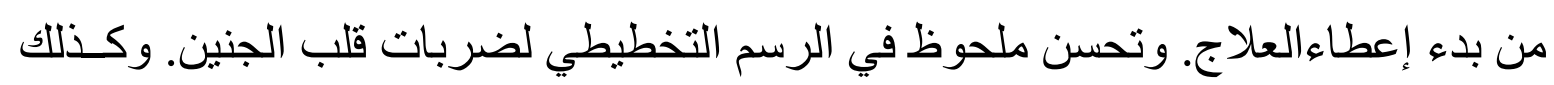

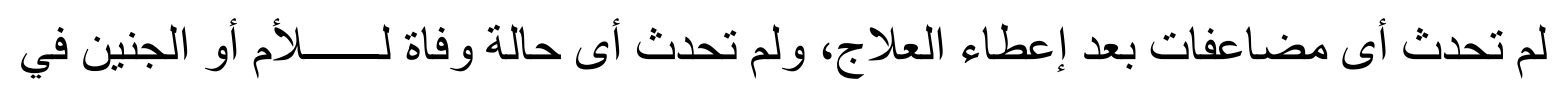

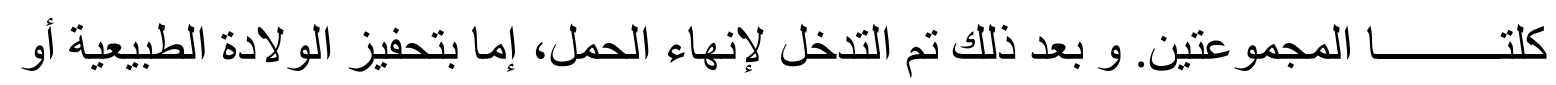
التدخل الجر احي بإجر اء عملية قيصرية.

الإسـتنتاج: كـان تأثثر عقار النيتروجلسرين، والـذي تم إعطاؤه عـن طريـق الوريد لعلاج

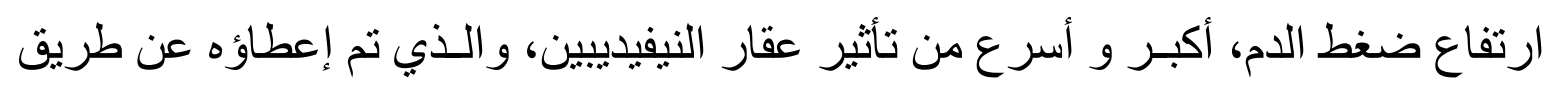
الفم، وكذلك كان عقار النيتروجلسرين ممائلا لعقار النيفيديبين من حيث الأمان و الفاعلية. 